therapeutic use in human cancer. European Journal of Cancer 1994; 30A: 2170-80

${ }^{9}$ Bradford MM. A rapid and sensitive method for the quantification of microgam quantities of protein utilizing the principle of protein-dye binding. Analytical Biochemistry. 1976; 263(32): 16626-30

${ }^{10}$ Oliva MLV, Sampaio UM, Sampaio CAM. Serine and SHproteinase inhnibitors from Enterolobium contortisiliquum beans. Purification and preliminary characterization. Brazilian Journal of Medical and Biological Research. 1988; 20: 767-70

${ }^{11}$ Morrison JF. The slow binding and slow tight-binding inhibition of enzyme-catalysed reactions. Trends in Biochemical Sciences. 1982; March:102-5

${ }^{12}$ Laemmli UK. Cleavage of structural proteins during the assembly of the head of bacteriophage T4. Nature. 1970; 227 (259): 680-685

\section{Bioactive derivatives obtained from lecanoric acid, a constituent of the lichen Parmotrema tinctorum (Nyl.) Hale (Parmeliaceae)}

\author{
Alcir Teixeira Gomes'; Neli K. Honda ${ }^{1 *}$; Fernanda Mesquita \\ Roese'; Rozanna M. Muzzi'; Maria Rita Marques² \\ 1 Departamento de Química, Universidade Federal de Mato \\ Grosso do Sul, 79070-900, Campo Grande, MS \\ 2 Departamento de Morfofisiologia, Universidade Federal de \\ Mato Grosso do Sul, Campo Grande, MS, Brazil \\ nkhonda@nin.ufms.br
}

\begin{abstract}
With the aim of obtaining new compounds with potential antifungal activity, lecanoric acid, a chemical constituent of the lichen Parmotrema tinctorum and its derivatives prepared from structural modification were tested against the fungus Cladosporium sphaerospermum, by employing the bioautographic method. Activity of the derivatives ranged from 10 - to $1-\mu \mathrm{g}$ concentrations. Results demonstrated this series of compounds to have potent fungitoxic activity.
\end{abstract}

The search for new substances with antifungal activity has received increased attention over the past years, since few antifungal agents, and of limited action, are available for the treatment of systemic mycoses. ${ }^{1}$

Many compounds isolated from lichens have been effective in inhibiting growth of fungi and bacteria. ${ }^{2}$

In order to obtain compounds with potential activity against fungi, some derivatives of lecanoric acid (1), the main component of the lichen Parmotrema tinctorum, were prepared.

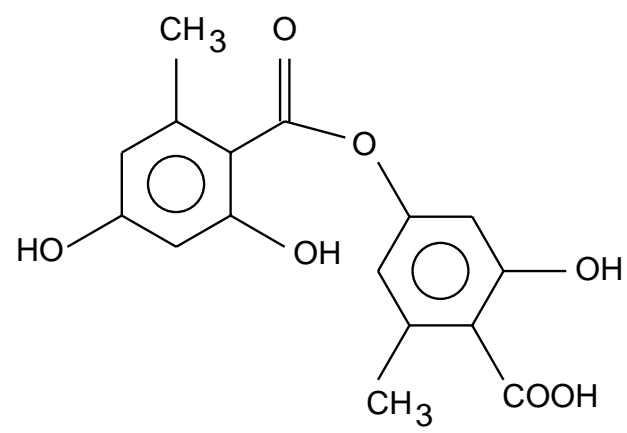

(1) Lecanoric acid

Alcoholisis of the acid led to the synthesis of the following derivatives: methyl (I), ethyl (II), $n$-propyl (III), $n$-butyl (IV), $n$ pentyl (V), iso-propyl(VI), $s$-butyl (VII), and $t$-butyl (VIII) orsellinates (2). Their structures were confirmed by IV, RMN ${ }^{1} \mathrm{H}$ 
(300 MHz), ${ }^{13} \mathrm{C}(75 \mathrm{MHz}), \mathrm{COSY}{ }^{1} \mathrm{H}-{ }^{13} \mathrm{C}$, DEPT 135 , and mass spectral data.<smiles>Cc1cc(O)cc(O)c1C(=O)O</smiles>

$\mathrm{R}=$ (I) $-\mathrm{CH}_{3}$; (II) $-\mathrm{CH}_{2} \mathrm{CH}_{3}$; (III) $-\mathrm{CH}_{2} \mathrm{CH}_{2} \mathrm{CH}_{3}$; (IV) $-\mathrm{CH}_{2}\left(\mathrm{CH}_{2}\right)_{2} \mathrm{CH}_{3}$; (V) - $\mathrm{CH}_{2}\left(\mathrm{CH}_{2}\right)_{3} \mathrm{CH}_{3} ;(\mathrm{VI})-\mathrm{CH}\left(\mathrm{CH}_{3}\right)_{2} ;(\mathrm{VII})-\mathrm{CH}\left(\mathrm{CH}_{3}\right)\left(\mathrm{CH}_{2} \mathrm{CH}_{3}\right)$; (VIII) $-\mathrm{C}\left(\mathrm{CH}_{3}\right)_{3}$

\section{(2) Orsellinates}

Antifungal activity of the homologous series of orsellinates (I-IV) was verified to a concentration as low as $1 \mu \mathrm{g}$. The same behavior was observed for $t$-butyl and $s$-butyl orsellinates (VIII and VII). On the other hand, $n$-pentyl orsellinate (V) inhibited growth of Cladosporium sphaerospermum to a $5-\mu \mathrm{g}$ concentration, whereas $i$-propyl orsellinate (VI) was active to a concentration of $10 \mu \mathrm{g}$. Lecanoric acid did not display activity against this fungus in any the test concentrations, but anfotericin B $\left(\right.$ Fungizon $\left.^{\circledR}\right)$, used as the control substance, presented activity to concentrations as low as $5 \mu \mathrm{g}$. The results obtained through bioautography ${ }^{3,4}$ demonstrate that the compounds prepared are promising antifungal agents. Furthermore, it was possible to verify by means of structure-activity correlation that the ramification present in the carbon chain has an influence on the activity.

\section{Material and Methods}

The lichen Parmotrema tinctorum was collected in Mato Grosso do Sul, southwestern Brazil, in March 1999. (Voucher specimen number 0488 is deposited in the Herbarium of the Chemistry Department of Universidade Federal de Mato Grosso do Sul at Campo Grande.) Lecanoric acid was isolated and purified according to Ahmann et al. ${ }^{5}$

Preparation of orsellinates ${ }^{6}$ : The derivatives were prepared by reacting lecanoric acid with its corresponding alcohols in a reflux system. After 20 hours of reaction, the alcohol was evaporated and the products of reaction were separated in a silica gel chromatographic column.

Bioautography: Cladosporium sphaerospermum was cultivated according to Figueiredo et al. ${ }^{7}$ Initially, solutions of each substance, in concentrations of 50, 25, 10, 5 and $1 \mu \mathrm{g}$ (always in $25 \mu 1$ of acetone), were applied over 20 -cm 20 -cm glass plates coated with silica gel. The plates were then sprayed with a suspension of Cladosporium sphaerospermum spores in the concentration of $4.87 \times 10^{7}$ spores $/ \mathrm{ml}$.

Activities were evaluated by observing the inhibition zones of Cladosporium sphaerospermum growth.

\section{Acknowledgements}

Financial support from CNPq-PROPP-UFMS and CNPq is gratefully acknowledged. Thanks are due to Dr. Mariana Fleig for the identification of the lichen. A.T.G. also wishes to thank CAPES for the grant provided.

\section{References}

${ }^{1}$ Murray PR, Rosenthal KS, Kobayashi GS, Pfaller MA. Medical Microbiology. 3.end. St. Louis: Guanabara Koogan, St. Louis, 2000

${ }^{2}$ Asahina Y, Shibata S, Chemistry of lichen substances. Tokyo: Japan Society for the Promotion of Science. 1954

${ }^{3}$ Penzes LP, Oertel GW. Direct bioautography on thin-layer chromatograms as a method for detecting fungitoxic substances. Journal of Chromatography. 1970; 51:327-9

${ }^{4}$ Rahalison L, Hamburger M., Frenk E, Hostettmann K. Antifungal tests in phytochemical investigations: Comparison of bioautographic methods using phytopathogenic fungi and human pathogenic fungi. Planta Medica. 1993; 60: 41-4

${ }^{5}$ Ahmann GB, Mathey A. Lecanoric acid and constituents of Parmelia tinctorum and Pseudoevernia intensa. Bryologist. 1967; 70(1): 93-7

${ }^{6}$ Bachelor FW, Cheriyan UO, Wong JD. Cleavage of depsides by tert-butyl alcohol. Phytochemistry. 1979; 18: 487-8

${ }^{7}$ Figueiredo MB, Pimentel CP. Métodos utilizados para conservação de fungos na micoteca da seção do Instituto Biológico. Summa Phytopathologica. 1975; 1(4): 299-302 